\title{
IMAGEM, MAGIA E IMAGINAÇÃO: DESAFIOS AO TEXTO ANTROPOLÓGICO*
}

Sylvia Caiuby Novaes

\section{Imagem e texto - uma relação tensa}

Lemos um texto, olhamos uma imagem. De modos muito diversos ambos comunicam. Tanto as palavras e as frases que lemos em um texto, quanto as formas e as cores que vemos na imagem expressam algo sobre o mundo. A comparação entre imagem e texto é uma constante para aqueles que se dedicam à antropologia visual. Na verdade, esta é uma comparação antiqüíssima; desde Leonardo da Vinci, as diferentes formas de expressão artística, como a pintura e a poesia, são comparadas.

O termo texto tem uma acepção clara - as palavras de um autor expressas em livro ou em qualquer outro escrito - e deriva do latim textum, entrelaçamento ou tecido. Certamente são muitos os tipos de texto: acadêmico, literário, poético, jornalístico, publicitário e assim por diante. No entanto, em todos se percebe a tessitura das palavras do autor, mesmo quando este não é nomeado. Tal não ocorre com a imagem. Como bem observa Mitchell (1986), as imagens também podem ser de vários tipos: gráficas (como as pinturas, as estátuas e os desenhos); óticas (como os reflexos no espelho e as projeções); perceptivas (como as aparências); mentais (como os sonhos, as memórias, as idéias); verbais (como as metáforas e as descrições). Vale notar que, de modo geral, textos remetem à autoria, ao passo que imagens são quase sempre remetidas ao referente que elas apresentam. Parece haver uma distância entre o texto e aquilo sobre o que ele fala; já as imagens estão sempre próximas do que apresentam. Barthes (1990:27) afirma que "segundo uma antiga etimologia, a palavra imagem deveria estar ligada à raiz de imitari".

Há algo na imagem que a afasta da racionalidade que tanto tem marcado as nossas ciências sociais. Parece-me absolutamente procedente a hipótese de Olgária Matos quando supõe uma origem comum, no persa antigo, para imagem e magia. Definida como "instância intermediária entre o sensível 
e o inteligível", a imagem é a "imaterialidade material" (1991:16). O termo francês magie vem do grego mageia (de magos, mage): arte de produzir efeitos maravilhosos pelo emprego de meios sobrenaturais e, particularmente, pela intervenção de demônios. Ao contrário da religião - que tende à metafísica e às abstrações intelectuais - a magia é um "tesouro de idéias"; como afirmou Marcel Mauss (2003), a magia apaixona-se pelo concreto e dedica-se a conhecer a natureza, estabelecendo um índice de plantas, animais, metais e um primeiro repertório das ciências físicas, astronômicas e naturais. Para Mauss, a magia é sempre a técnica mais fácil - a própria magia cria imagens.

Também Vernant aproxima a imagem de um mundo outro, mostrando o processo que leva ao desenvolvimento das imagens a partir dos ídolos, das atualizações simbólicas das diferentes modalidades do divino. Só após um longo processo, que culminou na confluência dos séculos V e IV antes de nossa era, foi que a imagem passou a ser "concebida como um artifício imitativo que reproduz, sob a forma de falso semblante, a aparência exterior das coisas reais" (Vernant 1990:318). A partir desse momento, segundo o autor, a imagem começa a depender do ilusionismo figurativo, da faculdade da mimesis, deixando de se aparentar com o domínio das realidades religiosas. É exatamente a este sentido de imagem que me refiro neste texto, deixando de lado as que são poéticas, mentais ou perceptivas.

Ao contrário do texto, as imagens são universais, pois existem em todas as culturas humanas. Mas são igualmente artefatos culturais; parafraseando Lévi-Strauss, a imagem é uma apropriação que a cultura faz da natureza. Imagens não reproduzem o real, elas o representam ou o reapresentam. Nenhuma delas é idêntica ao real. Por outro lado, como diz este autor em entrevista a Charbonnier (Lévi-Strauss 1969:97), se não houvesse nenhuma relação entre a imagem e o objeto que ela representa, estaríamos diante de um objeto de ordem lingüística e não diante de uma imagem. A linguagem, desde Saussure, é um sistema de signos que não tem relações materiais com aquilo que representa. Por outro lado, se a imagem fosse uma imitação completa do objeto, já não seria um sistema de signos.

Imagens, especificamente as que resultam das modernas técnicas de reprodução, como as fílmicas ou fotográficas, são signos que pretendem completa identidade com a coisa representada, como se não fossem signos. Iludem-nos em sua aparência de naturalidade e transparência, a qual esconde os inúmeros mecanismos de representação de que resultam. Eficientes na comunicação simbólica, sem constrangimento sintático, estas imagens podem ser eloqüentes. Por isso mesmo elas mantêm com o discurso verbal em que o significado parece claro e manifesto - uma relação tensa, como 
uma disputa de território. Se o sentido do texto nos dá a impressão de ser único e fixo (embora seja, também ele, passível de várias leituras) e capaz de abstrações e generalizações, imagens têm uma natureza paradoxal: por um lado, estão eternamente ligadas a seu referente concreto, por outro, são passíveis de inúmeras "leituras", dependendo de quem é o receptor.

De modo cada vez mais freqüente, as imagens vêm sendo estudadas como forma de linguagem. Entretanto, na relação imagem/palavra, a tendência foi por muito tempo associar a imagem à natureza e a palavra à convenção.

Este parece ser um dos motivos que afastaram os cientistas sociais de uma maior proximidade com o estudo de imagens. Foi também a partir dessa perspectiva que Freud demonstrou a incapacidade de sonhos expressarem conexões lógicas, verbais. Para ele as artes plásticas, como a pintura, a escultura e o desenho, têm uma limitação semelhante, se comparadas com a poesia, que pode fazer uso da fala. A psicanálise é a ciência das "leis de expressão", a arte da escuta que governa a interpretação da imagem onírica muda. "A restauração das conexões que a elaboração do sonho destruiu é uma tarefa que tem que ser realizada pelo processo interpretativo" (Freud 1972:332). Através da psicanálise se pode extrair a mensagem verbal escondida na superfície pictórica enganosa e inarticulada dos sonhos.

Na visão de Freud, a imagem está associada à natureza e a palavra à convenção. Nessa perspectiva, que se mantém até hoje nas ciências sociais, nunca se percebe o quanto a imagem é estruturada pelas normas e pelas convenções de diferentes culturas. A possibilidade da fala, elemento básico que nos distingue dos animais, estabeleceu por anos a primazia da palavra sobre a imagem. Nesta distinção, a natureza sempre foi vista como algo objetivo, biológico, universal e a convenção, como algo social, cultural, regional ou local.

$\mathrm{Na}$ antropologia, esta dualidade imagem/palavra e sua associação com o par natureza/cultura começou a ser superada a partir de pesquisas mais ligadas à importância da memória nas chamadas sociedades sem escrita. Carlo Severi, por exemplo, organizou todo um volume da revista L'Homme, publicado em 2003, em que os diferentes artigos aproximam a perspectiva estética e a perspectiva etnográfica para compreender objetos, imagens, pinturas corporais, estátuas etc. Na sua contribuição a esta revista, Severi, como outros autores deste número de L'Homme, retoma a obra de Aby Warburg e propõe uma investigação das relações entre linguagem e iconografia nas sociedades ágrafas. Warburg oferece uma perspectiva central para os artigos reunidos neste volume da revista por sugerir a necessidade da imagem e enfatizar seu papel no processo de pensamento e na constituição de uma tradição. 


\section{Imagem e magia}

Uma questão freqüentemente ignorada pelos cientistas sociais é aquela em que é apenas o homem quem fabrica, reconhece e atribui sentidos às imagens. Imagens criadas pelo homem são tão antigas quanto a própria humanidade. Mãos marcadas na rocha ou na argila, as chamadas mãos em negativo, criadas soprando-se uma nuvem de pó colorido sobre a mão apoiada em pedra lisa, estão presentes em diversos sítios arqueológicos e são consideradas as imagens mais antigas produzidas pelo homem. Animais pintados em fundos de cavernas - quando se supõe que viviam na parte da frente destes locais, onde foram encontrados esqueletos, armas e ferramentas correspondem a um período posterior. Cavalos, touros, bisontes tornaram famosas as cavernas de Lascaux, na França, e Altamira, na Espanha. Se as nossas pinturas rupestres na serra da Capivara, no Piauí, e na caverna da Pedra Pintada, no Pará, têm cerca de 10 a 12 mil anos, aquelas registradas na Europa, como as recentemente descobertas na cidade de Vilhonneur, na França, podem chegar a 25 mil anos. ${ }^{1} \mathrm{O}$ fato é que as imagens nos acompanham desde pelo menos o Paleolítico.

As hipóteses quanto aos sentidos e aos objetivos dessas imagens variam de acordo com a época em que foram estudadas e a perspectiva teórica adotada. Não eram decorativas ou ornamentais, pois há inúmeras que se sobrepõem, apesar da enorme disponibilidade de espaço. São, por outro lado, muitas as cavernas distantes umas das outras que apresentam pinturas semelhantes. Hauser (1968) aposta numa interpretação que é hoje em dia amplamente utilizada para a análise de outros fenômenos pela antropologia, embora não mais para as pinturas rupestres. Para ele, algumas obras de arte são criadas para serem vistas, outras simplesmente para que existam. As pinturas rupestres perseguem objetivos mágicos, com animais freqüentemente representados atravessados por flechas ou lanças, além do desenho de figuras humanas disfarçadas em animais, ocupadas em danças mágicas. São pinturas naturalistas. "Uma representação cujo fim era criar um duplo do modelo - ou seja, não apenas indicar, imitar, simular e sim, literalmente, substituir, ocupar o lugar do modelo" (Hauser 1968:23). Segundo este autor, a pintura permitia ao caçador do paleolítico chegar à coisa mesma. "Pensava que com o retrato do objeto havia adquirido poder sobre ele" (idem:20).

Esta interpretação não difere daquela apresentada por Michael Taussig ao retomar os trabalhos de Frazer e Benjamim quanto à mimesis. Para Taussig, a faculdade mimética é "a natureza que a cultura usa para criar uma segunda natureza, a faculdade de copiar, imitar, criar modelos, explorar diferenças, 
entregar-se e tornar-se Outro. A magia da mimesis está no ato de desenhar e copiar a qualidade e o poder do original, a tal ponto que a representação pode até mesmo assumir aquela qualidade e poder" (1993:xiii, tradução minha). Voltamos aqui à aproximação, já aludida, entre imagem e magia.

\section{Diferentes formas de engajamento propiciadas pela imagem e pelo texto}

Se texto e imagem comunicam e se toda comunicação depende de uma relação entre aqueles que se comunicam, gostaria de me deter nas diferentes formas de engajamento que texto e imagem propiciam.

Uma imagem representa, no sentido bem simples de que ela torna presente qualquer coisa ausente: a rainha Elizabeth, o Papa João Paulo II, minha correspondente no Japão, a catedral da Sé, uma divindade qualquer. Assim, ela representa algo ausente, reproduzindo aspectos de sua aparência visível ou daquilo que se estabeleceu como a sua aparência. Ela imita, mas sem ser idêntica àquilo que representa.

Palavras por sua vez significam imagens mentais impressas na mente em função da nossa experiência com objetos. Uma palavra é a imagem de uma idéia e uma idéia é a imagem de uma coisa, como numa cadeia de representações. Palavras podem ser mais reais do que a própria coisa à qual elas se referem, por exemplo, quando a cena que descrevemos tem mais impacto do que a situação em si que vivenciamos. É o que faz o poeta ao descrever a paisagem. Nesse sentido, também a poesia pode ser vista como uma forma de produção pictórica.

Ao dar continuidade a esta comparação entre texto e imagem, poesia e pintura, poderíamos dizer que a poesia existe na dimensão do tempo, ao passo que a pintura existe na dimensão do espaço. Na clássica definição de Saussure (1969), a linguagem tem uma dimensão que tanto se expressa num tempo sincrônico e diacrônico (a língua), como num tempo irreversível (a fala). A poesia articula sons numa seqüência temporal; as representações gráficas e as imagens fixas, como a fotografia, existem na dimensão do espaço. Na disputa entre elas, segundo Wolff (2005), há quatro modalidades essenciais do ser que a linguagem pode dizer e que a imagem é incapaz de fazê-lo. No entanto, para este autor, são exatamente estas impotências que fazem toda a potência da imagem. Segundo ele:

1. A imagem ignora o conceito. Podemos representar Maria, mas não a mulher; podemos representar um cachorro, mas não o reino animal. Generosidade, classes 
sociais, tempo são conceitos e, como tais, impossíveis de serem representados pela imagem. Sem possibilidade de conceituar, a imagem não compara, não generaliza, não induz ou deduz, ou seja, ela nada explica. Para Wolff é esta a potência da imagem: o que ela pode mostrar nada pode dizê-lo. Podemos ler artigos sobre a fome na África, análises, informações, dados estatísticos. Imagens podem ser mais eloqüentes. Kevin Carter, fotógrafo sul-africano, ganhou em 1994 o Prêmio Pulitzer de fotografia ao retratar uma menina sudanesa esquálida e moribunda, tendo a seu lado um abutre que apenas aguardava seu momento final. Sabe-se que o fotógrafo cometeu suicídio meses após o prêmio. Não são apenas as fotografias que nos emocionam pelo sentido de realidade que proporcionam. Como cientistas sociais, já lemos inúmeros textos críticos a respeito de instituições como o Estado, a Igreja, o Exército e a família. As gravuras de Goya que comoveram o século XVIII continuam a causar em nós um grande impacto pela força daquilo que apresentam imageticamente. ${ }^{2}$ Apocalypse Now, filme de 1979 de Francis Ford Coppola, certamente aproxima o espectador dos horrores da guerra do Vietnam de um modo inigualável. Eu mesma procurei tratar da desigualdade socioeconômica no Brasil num videoclipe em que a frieza dos dados estatísticos pudesse ser substituída pela ironia das fotos de revistas como Caras e Chiques e Famosos, tendo como pano de fundo a música Fim de Semana no Parque, dos Racionais. ${ }^{3}$

2. A imagem mostra afirmando, ela é incapaz de negar. A imagem de um cachimbo diz, sem o dizer, que o que lá está é um cachimbo. Quando Magritte acrescenta - "Isto não é um cachimbo", alertando-nos que se trata de mera representação da coisa e não da coisa cachimbo, só pode fazê-lo através de palavras. É o texto que diz aquilo que a imagem é incapaz de dizer. A força da imagem está assim em dizer, melhor do que a palavra, o que a coisa é.

3. O único modo gramatical da imagem é o indicativo. A imagem ignora as nuances do subjuntivo ou do condicional. Não há SE ou TALVEZ na imagem. A imagem É. Daí seu poder de despertar o chamado sentimento de realidade que a linguagem não dá. Vem daí sua força de convicção aparente. ${ }^{4}$

4. O único modo da imagem é o indicativo e o único tempo o presente. A imagem ignora pretérito e futuro. Nada na imagem do papa João Paulo II diz se ele está vivo ou morto. Vem daí, segundo Wolff, a força religiosa da imagem: ela faz reviver os mortos, torna presente a vida dos santos nas paredes das igrejas, atualiza na cruz o martírio de Cristo. Seu poder na esfera do sagrado é tal que ela não mais representa o deus; é o próprio deus que se apresenta nela. Se o tempo do sagrado é o tempo do eterno, em que nada se transforma, este é também o tempo da imagem. 
A imagem tem esse poder de representar a realidade ausente ou distante, aquela que não pode estar presente aos nossos sentidos. A ilusão não consiste em confundir a imagem com a realidade.

A ilusão criada pela imagem é a ilusão do fantasma ou do ícone. [...] Daí o poder de engajamento entre a imagem e seu receptor. Não vemos a imagem, só vemos a própria coisa representada, por transparência; vemos o modelo e não a imagem; é ao modelo que atribuímos o poder da imagem, o de se tornar presente (Wolff 2005:25-27; 38).

Daí também o grande perigo, ou a grande potência da imagem: fazer crer que ela não é uma imagem, fazer-se esquecer como tal. O engajamento com a imagem propicia a realidade representada, jamais a realidade da representação.

Vem daí, certamente, a enorme resistência de várias sociedades indígenas às fotos que não-índios insistem em tirar quando vão visitá-los. Entre os Bororo do Mato Grosso, que conheço bem, tudo o que existe de uma pessoa deve ser destruído após a sua morte. Seus pertences, suas roupas, artefatos, inclusive sua casa. Mesmo seu nome deixa de ser pronunciado. Até pouco tempo atrás, seria inconcebível para os Bororo contemplar a foto de um morto. É como se o finado, através da imagem, retornasse para este mundo, onde ele não tem mais lugar após o funeral que a sociedade dedicou à sua alma por três longos meses. A fotografia impediria que se levasse a cabo esta necessidade de destruição de toda a presença do morto neste mundo. Como diz Bazin, "a fotografia não cria, como a arte, eternidade, ela embalsama o tempo, simplesmente o subtrai à sua própria corrupção" (Bazin 1991:24).

A imagem compartilha com a magia não apenas uma mesma origem etimológica, mas várias outras características que merecem ser explicitadas e que talvez permitam melhor entender a relação que se estabelece entre a imagem e o espectador. Não se trata aqui de atribuir crenças supersticiosas às pessoas que olham imagens, mas sim de verificar processos de engajamento que são efetivamente muito semelhantes. Tylor (1958 [1871]) já afirmava que são duas as fórmulas dominantes na magia: as leis de contigüidade e de similaridade. Ou, como retomado por Mauss, "as coisas em contato estão ou permanecem unidas, o semelhante produz o semelhante" (Mauss 2003:100). Ora, estas parecem ser as características da imagem (fotográfica, principalmente) que mais fascinam aqueles que a contemplam. Não são apenas os índios que vêm na imagem do morto a sua presença.

Alfred Gell (1998) demonstra que a necessidade de controle sobre a própria imagem não se restringe às populações indígenas, é algo muito comum 
a todas as pessoas. O autor não vê razões para invocar crenças mágicas ou animistas para afirmar que as pessoas são muito vulneráveis às representações hostis que delas podem ser feitas. Isto porque a agência do indivíduo está efetivamente impressa na representação. Como pessoas sociais, estamos presentes não apenas em nosso corpo físico, mas em tudo o que nos rodeia e que testemunha nossa existência, nossos atributos, nosso agir. Nesse sentido, eu sou a causa da forma que minha representação assume. Mais do que isto, a imagem pode exercer um efeito causal na direção oposta, sobre a pessoa que ela representa, tal como ocorre em alguns rituais (Gell 1998:102-103). ${ }^{5}$

Em outros termos, se adotarmos uma perspectiva relacional, como proposta por Gell, e atentarmos para o papel de mediação das imagens nos processos sociais, poderemos melhor perceber o modo como elas fazem a mediação da agência social no seu engajamento com o receptor. Vale lembrar que Gell se mostra preocupado, neste seu livro, com imagens religiosas e artísticas, imagens materializadas, bi ou tridimensionais, e eu aqui me refiro às imagens de modo geral, principalmente àquelas que derivam das modernas técnicas de reprodução.

Neste sentido, a imagem — particularmente a imagem fotográfica tem um aspecto indicial que vem sendo ressaltado por vários especialistas. Como diz Dubois (1992), há uma pregnância do real na fotografia. A tal ponto o real se apresenta na foto, a tal ponto ela é o analogon perfeito do real que Barthes (1990) chega a definir a fotografia como uma mensagem sem código. Para este autor, é a analogia mecânica entre a fotografia e o real que ela expõe que impede a descrição da foto. Em outra de suas obras dedicadas à fotografia (Barthes 1984), ele afirma que a aderência do referente à fotografia caracteriza-a e distingue-a de todas as outras imagens.

Num texto curto e denso, Bazin (1991) mostra que a originalidade da fotografia em relação à pintura advém de sua objetividade (as lentes da câmera fotográfica são, inclusive, denominadas objetivas), que lhe confere um poder de credibilidade que se encontra ausente em qualquer outra obra pictórica. Nas palavras deste autor, "A fotografia se beneficia de uma transferência de realidade da coisa para a sua reprodução" (1991:22). Esta me parece ser a magia da imagem. A relação profunda que imagem e magia mantêm proporciona, no caso da primeira, uma possibilidade de engajamento muito específica com quem a contempla. Além da enorme semelhança entre a imagem e o real que ela representa, na fotografia o referente adere à imagem tal como nas práticas mágicas, em que se supõe que qualquer elemento que tenha tido contato com uma pessoa possa, pelo contágio, remeter a ela. A imaginação é, por outro lado, poderosa, tanto na magia quanto na contemplação de uma imagem. Ao definir a magia como 
a arte do fazer, Mauss destaca que ela "consegue substituir a realidade por imagens. Não faz nada ou quase nada, mas tudo faz crer, tanto mais facilmente quando põe a serviço da imaginação individual forças e idéias coletivas" (Mauss 2003:174).

Este engajamento que a imagem propicia leva muitos antropólogos a discutir sobre o conhecimento produzido por meio de textos e aquele que se produz através de imagens - fílmicas ou fotográficas. Na nossa disciplina, eminentemente verbal, o pensamento baseado em seqüências de imagens é distinto daquele que se baseia em uma seqüência de palavras e frases. Durante muito tempo, as fotos e os filmes etnográficos eram ilustrações do que o texto afirmava, objetivavam análises antropométricas ou o estilo corporal particular de uma cultura, em suma, fotos e filmes naturalistas que, como afirma George Marcus, ainda não contestavam as representações estabelecidas de temas específicos, de modo a alterar radicalmente a forma com que antropólogos pensam sobre seus temas de investigação (Marcus 1994:18).

MacDougall (1998) argumenta que uma das principais diferenças entre texto e imagem, em termos da produção do conhecimento antropológico, está na possibilidade de controle sobre o significado que o texto oferece quando comparado à imagem. Na descrição densa proposta por Geertz, por exemplo, os dados colhidos são canalizados através da linguagem, produzindo uma condensação do significado que praticamente os deixa para trás. Quando trabalhamos com imagens, é só com os dados efetivamente captados que podemos contar. O texto antropológico pode trazer algo equivalente, como os depoimentos dos informantes, mas estes não constituem o todo do texto. Neste sentido, talvez seja possível pensar a montagem, tal como foi proposta por Eisenstein, como uma tentativa do discurso visual de produzir algo que vá além das imagens efetivamente captadas, mesmo que se valendo delas e de sua justaposição para produzir novos sentidos. ${ }^{6}$

\section{A recepção não controlada das imagens}

O antropólogo que trabalha com imagens detém menos controle sobre as possibilidades de leitura que suas imagens trazem ao receptor; é sempre possível que o receptor se distraia diante dos objetivos do autor. Les maîtres fous (1955), um filme de Jean Rouch que mostra rituais de possessão, entre eles um em que os Hauka comem um cachorro, provocou intensas reações de intelectuais franceses e africanos. As imagens deste filme continuam a causar enorme impacto nos espectadores e o texto narrativo é praticamente ignorado por quem vê o filme. Todo o filme é acompanhado por comentários 
de Jean Rouch, que procura explicar o ritual apontando para a racionalidade que é própria dos Hauka, mostrando como eles representam e satirizam as autoridades coloniais. A narrativa de Rouch parece ser ignorada pelos espectadores, que se detêm nas imagens de possessão de homens babando, de rostos desfigurados, corpos em contorção, e de um cachorro sendo sacrificado e comido. Marco Antonio Gonçalves aponta para o fato de Rouch "criar uma tensão proposital entre as imagens inexplicáveis enquanto simples imagens para uma platéia que desconhece o ritual e um texto, que assume uma narração que torna o ritual algo racional" (2008:52-53).

Podemos ler um texto explicando o funeral yanomami, no qual as cinzas dos mortos são misturadas a uma papa e ingeridas pelos parentes. Um filme sobre o mesmo tema, mesmo que acompanhado por comentários que procurem explicitar o sentido do ritual, certamente encontrará enormes dificuldades em sua recepção. Exatamente no momento da recepção as imagens são polissêmicas. É por esta razão que, ao contemplar uma foto, freqüentemente o que se vê não é apenas o que ali está representado pela intenção do fotógrafo, mas o que ela evoca no universo das experiências pessoais de quem a contempla.

Num texto expositivo, há um encadeamento de idéias que é apresentado pelo autor, exatamente como estou propondo agora ao desenvolver este tema relacionando imagem e texto. Mostro a quem me lê ou me escuta a disputa entre imagem e texto, as potencialidades diferenciadas de cada um, o modo como engajam o leitor/espectador, a maneira como podem ou não ser apropriados pelo conhecimento antropológico. O mesmo não ocorre num filme ou vídeo, como bem o mostra MacDougall. Nos filmes, o importante é o princípio da descoberta a partir do encadeamento de imagens, que são ligadas por sua proximidade ou ressonância. É o receptor das imagens (e não o autor, como ocorre no texto) que vai fazendo a relação entre uma imagem e outra. O autor está certamente presente, apresentando o tema, mas cabe a quem vê o filme criar os predicados. É o espectador quem descobre as conexões entre uma rede de possibilidades estruturadas pelo autor. O espectador de um filme participa - na verdade, interage intensamente com aquilo que vê - de modo muito diverso daquele com que o leitor se relaciona com um texto (MacDougall 1998:68-71).

\section{Imagem e imaginação}

"A imagem começa a partir do momento em que não vemos mais aquilo que imediatamente é dado no suporte material, mas outra coisa e que 
não é dada por esse suporte" (Wolff 2005:20), ou seja, ao olharmos estabelecemos relações, "o sentido de uma imagem depende daquelas que a precedem, e sua sucessão cria uma realidade nova, que não é a simples soma dos elementos empregados" (Merleau-Ponty 1983:111). Como diz Merleau-Ponty, o filme dirige-se ao nosso poder de decifrar o mundo ou os homens; estamos envolvidos no filme, temos nele um papel central como espectadores. Se o texto nos diz sobre algo, o filme nos convida a descobrir.

Este processo de descoberta, principalmente nos filmes, é acompanhado por um processo de imaginação que ao mesmo tempo se nutre do imaginário social e o alimenta. É o que nos mostra Rose Satiko Hikiji (1998 a e b) ao analisar como o cinema de ficção contemporâneo colabora na construção de um cenário midiático que constitui o imaginário sobre a violência. A análise de filmes como Pulp fiction e Reservoir dogs (Cães de Aluguel), de Tarantino, e Estrada perdida, de David Lynch, permitem à autora concluir que "Mais que reflexo, ou re-apresentação da violência cotidiana das metrópoles, estas obras apropriam-se da violência para falar da contemporaneidade, das relações sociais, das nossas (nós, espectadores, cidadãos urbanos) relações com o outro, com o mundo, com as imagens. A violência é matéria-prima dos filmes porque, no limite, 'é boa para pensar'. Aponta as fronteiras fracamente demarcadas entre morte e vida, real e imaginário, o que tememos ser e o que somos" (Hikiji 1998a:128).

É possível afirmar que se o texto permite o conhecimento pela descrição, as imagens proporcionam conhecimento por meio da familiaridade, aquilo que os ingleses denominam de acquaintance. Em inglês, acquaintance tem também esse sentido de envolver direta/pessoalmente, mas é, por outro lado, um modo da cognição, que se dilui um pouco ao falar em experiência; não exatamente "conhecimento direto/pessoal"; uma "acquaintance" pode ser alguém que conhecemos pessoalmente, ainda que não intimamente, pode ser reconhecença. ${ }^{7}$ Filmes em que a temática principal é a violência nos levam a ter uma outra relação com o medo, permitem-nos certo tipo de "exercício ritual através do qual os espectadores-leitores aprendem a lidar com a violência cotidiana" (Hikiji 1998a:64).

Imagens favorecem, mais do que o texto, a introspecção, a memória, a identificação, uma mistura de pensamento e emoção. Imagens, como o próprio termo diz, envolvem, mais do que o texto descritivo, a imaginação de quem as contempla. Elementos visuais têm a capacidade de metáfora e sinestesia - relação subjetiva espontânea entre uma percepção e outra que pertença ao domínio de um sentido diferente. Podemos associar algumas formas ou objetos a pessoas ou seres específicos, certos cheiros evocam a 
infância etc. Esta capacidade de metáfora e sinestesia é muito mais acentuada nas imagens quando comparadas ao texto verbal.

Imagens não figurativas, como as artes gráficas carregadas de elementos geométricos, presentes em muitas sociedades indígenas, igualmente evocam respostas que engajam o receptor em processos de entendimento que dão forma concreta a uma concepção abstrata. Nestas sociedades, ao contrário da nossa, a estética não é concebida como campo autônomo e a palavra arte não figura no léxico de suas línguas. As imagens têm, nestas sociedades, uma enorme eficácia estética, como diz Gell (1998) e esta eficácia das imagens está relacionada ao poder dos seres que elas representam e que delas emana.

Veja-se, por exemplo, o caso das artes gráficas entre os Wauja, povo indígena do Alto Xingu. Suas máscaras e "roupas" com motivos gráficos de origem extra-humana, analisadas por Aristóteles Barcelos Neto, provocam uma emoção estética que tem, segundo o autor, motivações simbólicas. É por meio das artes gráficas que os Wauja domesticam os aspectos monstruosos dos seres sobrenaturais, o que permite que eles passem a ter com estes seres relações menos perigosas. Entender o significado do grafismo wauja implica entender a agência de seus criadores, pois estas criações não são apenas criações humanas, são a transferência de uma parte do mundo dos seres sobrenaturais para dentro da vida humana (Barcelos Neto 2002:153-199).

Els Lagrou (2007) analisa as duas linhas de força — alteridade e agência que se entrelaçam nos desenhos dos Kaxinawa, um povo indígena do Acre. Os Kaxinawa concebem o poder relacionado à capacidade de transformação: o poder que estes índios atribuem a seres espirituais denominados yuxin. Os padrões de desenhos kaxinawa são chamados de "a língua dos yuxin" e correspondem a um grafismo exclusivo das mulheres. O desenho kaxinawa, como mostra Lagrou, "alude a relações ligando mundos diferentes e aponta para a interdependência de diferentes tipos de pessoas" (2007:66). É exatamente esta capacidade de relacionar mundos e pessoas que confere aos desenhos sua capacidade de agir: "sobre os corpos, onde o desenho adere como uma segunda pele e sobre as mentes dos que viajam a mundos imaginários em sonhos e visões, onde a visualização do desenho funciona como mapa..." (idem).

Uma perspectiva muito semelhante para o estudo de imagens geométricas aparece numa obra de título bastante sugestivo - Ancestral connections: art and an aboriginal system of knowledge, em que Howard Morphy (1991) analisa a representação gráfica do conhecimento tradicional entre os Yolngu, do norte da Austrália. É esta arte evocativa, com motivos geométricos, que liga os Yolngu aos sonhos, o tempo da criação do mundo que, por 
meio do grafismo, continua no tempo presente. Toda a estética deste povo é um apelo aos sentidos e provoca uma resposta emocional naquele que a contempla. Ao focar especificamente o conceito de estética para este povo, Morphy demonstra em outro artigo (1992) que aquilo que é estética para os europeus, os Yolngu interpretam como a manifestação de um poder ancestral que vem do passado mítico. Os ancestrais estabeleceram uma "lei sagrada", mardayin, que consiste em um conjunto de músicas, danças, pinturas, objetos sagrados e encantações rituais associados aos seres ancestrais. Para os Yolngu "os mardayin não são apenas os meios de expressão de eventos ancestrais, mas também parte da essência dos próprios seres ancestrais. Eles fornecem uma forma de envolvimento direto com o passado ancestral" (Morphy 1992:186; tradução minha).

\section{Imagem, texto e experiência}

Imagens, por outro lado, favorecem a narrativa, algo que vem sendo estimulado pelos autores pós-modernos. Permitem compartilhar a experiência com o real, como o demonstram os filmes de Jean Rouch. Os textos, ainda apoiados em uma estrutura de tópicos (organização política, religiosa, econômica etc.), cuja origem se encontra nos topoi analisados por Frances Yates, têm uma enorme dificuldade em reconstruir a realidade investigada e propiciar ao leitor a experiência de conhecer e aproximar-se dela - a não ser autores que tenham um estilo narrativo eminentemente visual, como Malinowski. O modo como ele vai descrevendo a sociedade trobriandesa permite ao leitor visualizá-la nos mais ricos detalhes; são imagens da vida nativa e não representações abstratas. Nesse sentido, o trabalho de Malinowski revela, e é sua experiência pessoal neste mundo outro que permite um entendimento que define para ele o conhecimento que os antropólogos deveriam atingir - e que transforma o senso comum. ${ }^{8}$

Como diz Marcio Goldman, "a característica fundamental da antropologia seria o estudo das experiências humanas a partir de uma experiência pessoal" (Goldman 2006:167). A famosa fuga de Geertz, junto com os balineses, da polícia que os perseguia é um exemplo típico. Foi essa experiência que abriu, para Geertz, a possibilidade de uma etnografia em Bali. Igualmente, é esta experiência pessoal que marca os filmes de Jean Rouch e a sua antropologia compartilhada.

Das grandes descobertas que fazemos ao longo de uma pesquisa de campo, uma das mais recorrentes refere-se à opacidade que parece caracterizar toda a comunicação humana. No campo, é freqüentemente através da 
experiência que aprendemos, muito mais do que pela troca verbal com os nossos informantes. A experiência de algum modo nos afeta. Como mostra Marcio Goldman numa apresentação da obra de Jeanne Favret-Saada, no contexto da vivência de uma experiência de alteridade podemos ser afetados. Este afeto é o "resultado de um processo de afetar, aquém ou além da representação" (Goldman 2005:150). Para Favret-Saada, "a comunicação etnográfica ordinária - uma comunicação verbal, voluntária e intencional, visando à aprendizagem de um sistema de representações nativas — constitui uma das mais pobres variedades da comunicação humana. Ela é especialmente imprópria para fornecer informações sobre os aspectos não-verbais e involuntários da experiência humana" (Favret-Saada 2005:160).

Esta constatação não é muito diversa daquilo que MacDougall apresenta, ao acrescentar às modalidades de conhecimento propostas pela antropologia francesa - notadamente em Lévi-Strauss e Descola - uma outra. Ao conhecimento descritivo (domínio dos fatos), ao conhecimento estrutural (domínio das relações) e ao conhecimento explicativo (domínio da teoria), MacDougall acrescenta o conhecimento afetivo, aquele que vem do reconhecimento de algo familiar e que é do domínio da experiência.

Herdeira de uma tradição logocêntrica e eminentemente verbal, a antropologia tende a hierarquizar as modalidades de produção do conhecimento, colocando no topo a explicação, em seguida a descrição, e por último a experiência. No texto escrito essa hierarquia é nítida. Mesmo quando é a partir da experiência pessoal que o antropólogo tem seus insights e consegue elaborar sua etnografia, esta experiência geralmente desaparece no texto. ${ }^{9}$

Num artigo em que apresenta a tradução para o português de um texto de Victor Turner sobre a antropologia da experiência, John Dawsey mostra que esta publicação, de 1986, três anos após a morte de Turner, estimula os antropólogos a terem uma experiência, no próprio sentido etimológico da palavra: "do indo-europeu per, com o significado literal, justamente de 'tentar aventurar-se, correr riscos'. Experiência e perigo vêm da mesma raiz. A derivação grega perao, passar por, também chama a atenção de Turner pelo modo como evoca a idéia de ritos de passagem" (Dawsey 2005:163). Como lembra o autor, este texto de Turner foi publicado no mesmo ano em que saíram as publicações mais conhecidas da antropologia pós-moderna, como Writing culture (Clifford \& Marcus 1986) e Anthropology as cultural critique (Marcus \& Fisher 1986).

É esta experiência pessoal, implícita no ato mesmo do conhecimento, que pode ser claramente percebida em alguns trabalhos, nem sempre os mais conhecidos do público acadêmico. Dentre os que poderiam ser citados, 
destaco as fotografias de Pierre Verger e os filmes de Jean Rouch, não por acaso trabalhos que utilizam imagens. Pierre Verger era fotógrafo, etnólogo, autor de mais de 40 livros, nasceu em Paris, numa família de classe alta européia, de descendência belga e alemã. Recebeu o título de Babalaô Fatumbi - O Renascido - na África, em 1952. Na última entrevista concedida a Mário Cravo Neto, em 6 de fevereiro de 1995, cinco dias antes de falecer, Verger afirma que "O fato de ser nascido neste negócio de Ifá (um ritual do candomblé) me fez renascer. Essas pessoas seguramente têm uma percepção muito mais clara do que aquelas que estão fazendo raciocínio cartesiano. Sentem as coisas e sentem que o fato de ter feito a minha iniciação de babalaô me dava uma coisa nova, muito mais do que eu pensava". O outro a ser compreendido por este grande fotógrafo situa-se em outro universo, em outra cosmologia. Como afirma Maria Lucia Montes, esta é "uma cosmologia que se aprende - melhor diria se apreende - passo a passo, mas como uma experiência total, que impregna o corpo pelos cinco sentidos, invade a alma aos poucos e a transforma, à medida que vão sendo assimilados fragmentos de cosmogonias, movimentos de danças, de orikis, cantigas, os segredos das folhas, toques dos atabaques, o enredo de um orixá" (Montes 1996:13). ${ }^{10}$

Os filmes de Jean Rouch são também realizados por meio de uma metodologia que envolve o que ele chamava de antropologia compartilhada e cine-transe. As imagens do já mencionado Les maîtres fous são, segundo Renato Sztutman (2005:121), perigosas, em função deste aspecto tipicamente mágico que faz com que elas pareçam estabelecer com a possessão uma associação por contigüidade. O cine-transe permite a Jean Rouch filmar o real de modo a amplificá-lo, potencializando-o. O autor mostra que este antropólogo-cineasta procurava filmar o que via como se ele próprio estivesse em transe, de modo a aproximar o efeito do filme do efeito do ritual.

Além de um maior envolvimento do pesquisador, o trabalho com imagens parece responder também a uma outra questão que tem sido colocada por antropólogos com certa dificuldade em perceber a experiência individual quando são abordados fenômenos culturais. É também neste sentido que a preocupação de Turner, apontada por Dawsey — o convite à experiência tão bem expresso nos trabalhos de Verger e Rouch - parece fazer eco às dúvidas expressas por Sapir em 1934 e retomadas por MacDougall. Escrevendo em plena época dos estudos de cultura e personalidade, Sapir perguntava-se sobre a pertinência do conceito de cultura para entender a experiência individual. Propunha que se buscasse uma estrutura mais íntima da cultura, e comparava a fala concreta de um indivíduo aos sistemas mais formais e gramaticais que dela derivam. Para MacDougall, Sapir previu já 
naquela época o que seria a grande contribuição da antropologia visual: uma antropologia que focasse o que significa pertencer a uma cultura com toda a intrincada tessitura de experiências, e suas relações com o que é do domínio do costume e o que é do domínio pessoal.

\section{Conclusão}

Quero agora voltar à questão central que propus para desenvolver este tema que relaciona antropologia, imagem e texto - as diferentes possibilidades de engajamento que imagem e texto propiciam - e retomar esta discussão em termos das novas possibilidades da antropologia visual. No início da história da antropologia, o interesse pelas imagens estava ligado à sua aparência. Tais como as peças colecionadas pelos museus, acreditava-se que as imagens atestavam objetivamente uma realidade outra e poderiam contar a história da humanidade, mostrando-a ao observador. Foram também muitos os nativos levados à Europa para serem diretamente observados em feiras e exposições. Quando isto não era possível, a imagem — foto ou filme — lá estava, atestando ou substituindo a sua presença.

Em meados dos anos 1980, anunciava-se a já aludida crise da representação nas ciências sociais. Marcus e Fischer alertavam para o fato de que até mesmo nas ciências como a física e a matemática a tendência era concentrar-se menos em visões teóricas sobre a ordem e mais em micropadrões de desordem, como a teoria do caos da física, da química, da biologia e da matemática (Marcus \& Fisher 1986:8). Problemas de descrição nas ciências humanas passaram a ser vistos como problemas de representação.

A crítica pós-moderna estimulou novos estilos para a escrita antropológica, mas ao mesmo tempo estimulou novas formas de leitura. Os textos passam a despertar no leitor uma maior sensibilidade para as diferentes vozes ali presentes, para a relação entre escritores e leitores, entre o texto e seu objeto de investigação. Estas novas possibilidades de escrita e leitura, abertas pelos pós-modernos, constituem temas que vinham sendo debatidos pelos realizadores de filmes, desde Jean Rouch. Se antes o filme era um processo de descrição de uma cultura a ser inferido pelos espectadores, os trabalhos de Rouch passam a explorar as complexas redes de significado cultural e a posição dos diversos atores sociais envolvidos em determinada realidade social. Não há mais asserções ou conclusões finais sobre uma cultura. "Não se trata nem de mensagem, nem de representação, mas de um registro de engajamento com uma cultura diferente", como diz MacDougall (1998:75). A evocação torna-se mais importante do que a afirmação. E na 
evocação através das imagens, o papel do receptor é fundamental. Neste novo conceito de conhecimento antropológico, o significado não resulta apenas de uma reflexão sobre a experiência; ele necessariamente inclui a experiência - talvez de modo algo próximo àquele de alguém que se submete às práticas mágicas.

Recebido em 01 de outubro de 2007

Aprovado em 14 de maio de 2008

Sylvia Caiuby Novaes é Professora Associada no Departamento de Antropologia da Universidade de São Paulo e Coordenadora do Laboratório de Imagem e Som em Antropologia — LISA-USP. E-mail: <scaiuby@usp.br> 


\section{Notas}

* Muitos daqueles com quem convivi por anos como alunos são hoje colegas e meus interlocutores prediletos. Dentre estes, agradeço a Andréa Barbosa e a Rose Satiko Hikiji pela leitura e pelos comentários a uma primeira versão deste texto. Agradeço também a Aristóteles Barcelos Neto e Renato Sztutman pela leitura e pelos comentários estimulantes da segunda versão. A primeira versão deste texto foi apresentada nos Encontros de Sociologia e Antropologia, promovidos pelo IFCS-UERJ em setembro de 2007. Agradeço a Marco Antonio Gonçalves pelo convite para apresentá-lo.

${ }^{1}$ O Estado de S. Paulo, 7/2/2006, A13.

${ }^{2}$ Sobre as gravuras de Goya, vide Baudelaire et alii (1995). Uma excelente biografia de Goya foi publicada recentemente por Robert Hughes (2007).

3 "Exclusivos e Excluídos", artigo apresentado na mesa Mídia e Exclusão Social durante a XXIV ANPOCS (2000), acompanhado de um videoclipe de 2'50".

${ }^{4}$ Vale lembrar que neste artigo Wolff está interessado fundamentalmente nas imagens figurativas e, de preferência, naturalistas, e não nas imagens surrealistas ou abstratas.

${ }^{5}$ Gell retoma Yrjö Hirn, um autor de 1900, citado por Frazer. Para Hirn, as aparências das coisas materiais são partes constitutivas das coisas, a tal ponto que o poder que se pode exercer sobre uma pessoa ou uma coisa através do acesso à sua imagem é comparável ou até mesmo idêntico àquele que se obtém pelo acesso a uma parte física da coisa ou da pessoa. Aqui Gell introduz seu conceito de pessoa distribuída, ou seja, as partes de uma pessoa não estão todas fisicamente unidas e sim distribuídas pelo ambiente (Gell 1998:105-106).

6 “[...] dois pedaços de filme de qualquer tipo, colocados juntos, inevitavelmente criam um novo conceito, uma nova qualidade que surge da justaposição" (Eisenstein 1990:14).

${ }^{7}$ A respeito da diferença entre os princípios implícitos em meios visuais e no texto, vide MacDougall (1997:276-295).

${ }^{8}$ A respeito da narrativa eminentemente visual de Malinowski, vide Grimshaw (2001:44-56).

${ }^{9}$ Uma notável exceção encontra-se no artigo de 2003 de Marcio Goldman: "Os tambores dos mortos e os tambores dos vivos. Etnografia, antropologia e política em Ilhéus, Bahia".

${ }^{10}$ A respeito do conhecimento iniciático de Pierre Verger, vide o livro recentemente publicado por Jérôme Souty (2007). 


\section{Referências bibliográficas}

BARCELOS NETO, Aristóteles. 2002. A arte dos sonhos - uma iconografia ameríndia. Lisboa: Museu Nacional de Etnologia Assírio \& Alvim.

BARTHES, Roland. 1984. A câmara clara. Rio de Janeiro: Nova Fronteira.

. 1990a. "A mensagem fotográfica". In: O óbvio e o obtuso. Rio de Janeiro: Nova Fronteira. pp.11-25.

. 1990b. "A retórica da imagem". In: O óbvio e o obtuso. Rio de Janeiro: Nova Fronteira. pp. 27-43.

BAUDELAIRE, Charles et alii. 1995. Os caprichos de Goya. São Paulo: Editora Imaginário.

BAZIN, André. 1991. "Ontologia da imagem fotográfica". In: O cinema Ensaios. São Paulo: Editora Brasiliense. pp. 19-26.

CAIUBY NOVAES, Sylvia. 2000. "Exclusivos e excluídos". Texto e videoclipe $\left(2^{\prime} 50^{\prime \prime}\right)$, apresentados na XXIV ANPOCS, realizada em Petrópolis, entre 22 e 27 de outubro de 2000, na mesa Mídia e Exclusão Social.

CLIFFORD, James \& MARCUS, George. 1986. Writing culture. Berkeley: University of California Press.

CRAVO NETO, Mário. 1996. “Pierre Verger, o filho do trovão. Mário Cravo entrevista Pierre Verger". In: Pierre Verger, Bahia África Bahia. Catálogo publicado pela Pinacoteca do Estado de São Paulo, por ocasião da exposição fotográfica "Bahia África Bahia", realizada entre $18 \mathrm{de}$ maio e 5 de junho de 1996.

DAWSEY, John. 2005. "Victor Turner e a antropologia da experiência". Cadernos de Campo, 3:163-176.

DUBOIS, Philippe. 1992. O acto fotográfico. Lisboa: Editora Vega.

EISENSTEIN, Sergei. 1990. O sentido do filme. Rio de Janeiro: Jorge Zahar Editor.
FAVRET-SAADA, Jeanne. 2005. "Ser afetado". Cadernos de Campo, 13:155-161.

FREUD, Sigmund. 1972. A interpretação de sonhos. Edição Standard Brasileira das Obras Psicológicas de Sigmund Freud. Rio de Janeiro: Imago Editora Ltda.

GELL, Alfred. 1998: Art and agency, an anthropological theory. Oxford: Clarendon Press.

GOLDMAN, Marcio. 2003: "Os tambores dos mortos e os tambores dos vivos. Etnografia, antropologia e política em Ilhéus, Bahia". Revista de Antropologia, 46(2):445-476.

- 2005. "Jeanne Favret-Saada, os afetos, a etnografia". Cadernos de Campo, 13:149-153.

. 2006. "Alteridade e experiência: antropologia e experiência etnográfica". Etnográfica, X(1):161-173. Centro de Estudos de Antropologia Social (ISCTE), Lisboa.

GONÇALVES, Marco Antonio. 2008. O real imaginado - etnografia, cinema e surrealismo em Jean Rouch. Rio de Janeiro: Editora Topbooks (no prelo).

GRIMSHAW, Anna. 2001 . The ethnographer's eye - ways of seeing in modern anthropology. Cambridge: Cambridge University Press.

HAUSER, Arnold. 1968. Historia social de la literatura y el arte, vol. I. Madrid: Ediciones Guadarrama.

HIKIJI, Rose Satiko. 1998a. Imagemviolência - mimesis e reflexividade em alguns filmes contemporâneos. Dissertação de mestrado, PPGASUSP, São Paulo. . 1998b. "Uma estrada para o impenetrável". Sexta Feira, Antropologia, Artes e Humanidades, 2:192-197.

HUGHES, Robert. 2007. Goya. São Paulo: Companhia das Letras. 
LAGROU, Els. 2007. A fluidez da forma: arte, alteridade e agência em uma sociedade amazônica (Kaxinawa, Acre). Rio de Janeiro: Topbooks Editora.

LÉVI-STRAUSS, Claude. 1969. Entrevistas com Georges Charbonnier: arte, lenguaje e etnología. México: Siglo XXI (eds.), especialmente caps. 7 a 11. - 1997. Olhar, escutar, ler. São Paulo: Cia. das Letras.

MACDOUGALL, David. 1997. "The visual in anthropology". In: M. Banks \& H. Morphy, Rethinking visual anthropology. London: Yale University Press. pp. 276-295.

- 1998. "Visual anthropology and the ways of knowing". In: Transcultural cinema. Princeton: Princeton University Presss. pp. 61-91.

MARCUS, George \& FISCHER, Michael. 1986. Anthropology as cultural critique - an experimental moment in the human sciences. Chicago e Londres: The University of Chicago Press.

MARCUS, George. 1994. "The modernist sensibility in recent ethnographic writing and the cinematic metaphor of montage". In: Lucien Taylor (ed.), Visualizing theory, selected essays from V.A.R. 1990-1994. New York e London: Routledge. pp. 37-53.

MATOS, Olgária. 1991. "Imagens sem objeto". In: Adauto Novaes (org.), Rede imaginária: televisão e democracia. São Paulo: Cia das Letras. pp.15-37.

MAUSS, Marcel. 2003. "Esboço de uma teoria geral da magia". In: Sociologia e antropologia. São Paulo: Cosac \& Naify. Tradução de Paulo Neves. pp. 49-181.

MERLEAU-PONTY, Maurice. 1983. "O cinema e a nova psicologia". In: Ismail Xavier (org.), A experiência do cinema, antologia. Coleção Arte e Cultura, v. 5. Rio de Janeiro: Graal/ Embrafilme. pp.103-117.

MITCHELL, W. J. Thomas. 1986. Iconology - image, text and ideology.
Chicago: The University of Chicago Press.

MONTES, Maria Lucia. 1996. "O etnólogo feiticeiro". In: Pierre Verger, Bahia África Bahia. Catálogo publicado pela Pinacoteca do Estado de São Paulo, por ocasião da exposição fotográfica "Bahia África Bahia", realizada entre 18 de maio e 5 de junho de 1996.

MORPHY, Howard. 1992. "From dull to brilliant: the aesthetics of spiritual power among the Yolngu". In: J. Coote \& A. Shelton (orgs.), Anthropology, art and aesthetics. Oxford: Clarendon Press. pp. 181-208.

- 1991. Ancestral connections: art and an aboriginal system of knowledge. Chicago: The University of Chicago Press.

SAUSSURE, Ferdinand de. 1969. Curso de lingüística geral. São Paulo: Cultrix e Editora da Universidade de São Paulo. SEVERI, Carlo. 2003. "Warburg anthropologue, ou le déchifrement d'une utopie". L'Homme, 165:7-128, jan-mar. SOUTY, Jérôme. 2007. Pierre Fatumbi Verger - du regard détaché à la connaissance initiatique. Paris: Maisonneuve \& Larose.

SZTUTMAN, Renato. 2005. "Imagens perigosas: a possessão e a gênese do cinema de Jean Rouch". Cadernos de Campo, 14(13):115-124.

TAUSSIG, Michael. 1993. Mimesis and alterity, a particular history of the senses. New York: Routledge.

TYLOR, Edward. 1958 [1871]. Primitive culture. New York: Harper \& Row.

VERNANT, Jean-Pierre. 1990. Mito \& pensamento entre os gregos. Rio de Janeiro: Paz e Terra.

WOLFF, Francis. 2005. "Por trás do espetáculo - o poder das imagens". In: Adauto Novaes (org.), Muito além do espetáculo. São Paulo: Editora SENAC. pp.16-45.

YATES, Frances. 1966. The art of memory. Londres: Pimlico. 


\section{Resumo}

Quais as diferentes formas de engajamento que imagem e texto propiciam ao espectador/leitor? Sabemos que texto e imagem comunicam e que toda comunicação depende de uma relação entre aqueles que se comunicam; o objetivo deste texto é entender as novas possibilidades para a antropologia da expressão do conhecimento que se utiliza de imagens, como fotografias ou filmes.

Palavras-chave Antropologia visual, Imagem, Magia, Texto, Conhecimento

\section{Abstract}

What different forms of engagement do image and text allow the spectator/reader? We know that text and image communicate, and that all communication depends on a relationship between those who communicate. The objective of this text is therefore to understand the new possibilities available to an anthropology of the expression of knowledge that makes use of images, such as photographs and films.

Key words Visual anthropology, Image, Magic, Text, Knowledge 